\title{
Characteristics, Floristic Diversity and Structures of Stands Resulting from Assisted Natural Regeneration (ANR) in the Agroecozone of Tibiri in Niger
}

\author{
Younoussou Rabo ${ }^{1 *}$, Daouda Djadi Salifou ${ }^{1}$, Salamou Mahamane Tassiou ${ }^{1}$ And Ali Mahamane ${ }^{1,2}$ \\ ${ }^{1}$ Faculty of Agronomic Sciences, University of Diffa \\ Diffa, Niger \\ ${ }^{2}$ Garba Mounkaila Laboratory, Faculty of Science and Technology, Abdou Moumouni University of Niamey \\ Niamey, Niger \\ ${ }^{*}$ Corresponding author's email : raboyounoussou [AT] gmail.com
}

\begin{abstract}
The present study was carried out in the municipality of Tibiri where assisted natural regeneration is the method adapted by agriculture to maintain trees for various reasons. The general objective of this study is to characterize the floristic diversity and the structure of the woody stand resulting from assisted natural regeneration. The methodology adopted for this study consisted of inventories of woody species and regenerations in crop fields by placing plots of 50m $\times 50 \mathrm{~m}$ during the crop season. Thus twenty (20) plots were placed in the agrosystems according to homogeneity following an equidistance of $300 \mathrm{~m}$. The floristic survey made it possible to identify 19 species divided into 9 families of which the most represented are the Fabaceae (72\%). The most represented species are P. reticulatum (30\%), F. albida (17\%) and P. africana (14\%). These species also have the highest IVI values. The distribution of individuals by diameter class shows an "inverted $J$ " shape with the shape parameter $c=1.959(1<C<3.6)$, characteristic of populations with a predominance of young or small diameter individuals. The total regeneration density is 2648 stems / ha, grouped into eleven (11) species showing good regeneration and dominated by G. senegalensis representing 61.93\% of the density of the inventoried species followed by $P$. reticulatum $(14,80 \%)$.

ANR is a practice that contributes to improving the woody biodiversity of the fields where it is practiced. It is not only an alternative to greening the environment, but also provides several products and services to populations.
\end{abstract}

Keywords--- RNA, woody diversity, structure, Tibiri

\section{INTRODUCTION}

In the Sahel and particularly in Niger, woody species play an important role in the socio-economic and cultural life of populations. In fact, ligneous plants are part of the bio-geochemical cycle of production systems by providing biomass and / or necromass, creating a microclimate favorable to crops and protecting the soil against water and wind erosion (Breman et al., 1995; Young, 1995). In addition, the ligneous plants constitute important inputs in human and animal food, especially during hardship. Beyond that, they are a main source of energy and provide service wood, timber and traditional pharmacopoeia products for rural populations (Bonkoungou, 1993; Larwanou et al., 2006; Dan Guimbo et al., 2006; Dan Guimbo et al., 2010).

However, this woody vegetation is threatened by the combined actions of climatic deterioration and the anthropogenic factor (Boulain, 2004; Larwanou, 2005). As a result, during the 1970s and 1980s several publications were devoted to the energy crisis in the Sahel countries and elsewhere in arid and semi-arid zones (Eckholm, 1975, Winterbottom, 1980). The authors' main argument was that there was a large gap between the energy needs of the population, which was almost exclusively supplied by woods, and the annual growth of plant formations.

In addition and at the same time, the Sahel was going through a period of ecological crisis due to successive droughts. Agriculture also increasingly extended to remote areas where vegetation was largely destroyed. The perception was that in the Sahel, in the near future, areas around cities would be completely denuded due to the fuelwood needs because of their population that increase rapidly. For this purpose, the main finding is that the vegetation in the Sahel is deteriorating due to overexploitation by the population. This degradation is an undeniable fact, although field observations and studies also show significant areas of regreening (Olsson et al., 2005; Hermann et al., 2005).

With regard to this situation, farmers, by protecting shrubs and bushes resulting from natural regeneration, increased their self-resilience (Reij et al., 2009). This practice of rural communities in the southern strip of Niger, in 
particular Maradi and Zinder, called assisted natural regeneration (ANR), has enabled an increase in the density and diversity of trees. In fact, over the past three decades, around 200 million trees have grown on the cultivated fields of this southern strip (Tougiani et al., 2009). From a density of 2 or 3 trees per hectare on farms it evolved to 40; 60 or even more than 100 trees per hectare to today (Reij et al. 2009). Many authors (Seaquist et al., 2009; Tougiani, 2009; Bégué et al., 2011) have shown that in many regions of the Sahel, the trend towards woody degradation is reversed and we are witnessing a process of "re-greening" or "re-vegetation". Regreening, considered an increase in the Normalized Difference in Vegetation Index (NDVI) (Seaquist et al., 2009), is explained by changes in land use, natural resource management practices and agricultural practices, including techniques for preserving trees through assisted natural regeneration (Larwanou and Saadou, 2011; Sendzimir et al., 2011).

In Niger, these same authors have shown that re-greening takes place thanks to the rehabilitation efforts carried out by the various actors, including farmers, thanks to assisted natural regeneration. Like other localities in the Maradi region, ANR is a technique that is fully integrated into the producers' farming habits in the municipality of Tibiri.

Despite all the potential of natural resources, their socio-economic and pharmacopic role undergo intense degradation as a result of physical, agro-climatic and / or anthropogenic factors. Therefore, it is extremely important to deepen the knowledge in order to be able to provide all the information related to the assisted natural regeneration. The general objective of this study is to characterize the woody stand resulting from the assisted natural regeneration of the agro-ecological zone of Tibiri territory through the analysis of its floristic composition,-its-structure and ecological parameters.

\section{MATERIALS AND METHODS}

\section{$>$ Presentation of the study site}

The municipality of Tibiri-Gobir is located (Figure 1) in the eastern part of Guidan Roumdji department, in the region of Maradi. The climate is Sahelo-Sudanese with average annual rainfall of 500 to $600 \mathrm{~mm}$. The vegetation is composed of two types of carpet: the lower carpet composed mainly of: Eragrostis tremula, Cenchrus biflorus, Aristida longiflora and the upper carpet composed of Prosopis africana, Piliostigma reticulatum, Combretum glutinosum, Lannea microcarpa, etc. Agriculture is the main activity of the people. It is practiced by more than $90 \%$ of the population on about $80 \%$ of the land.

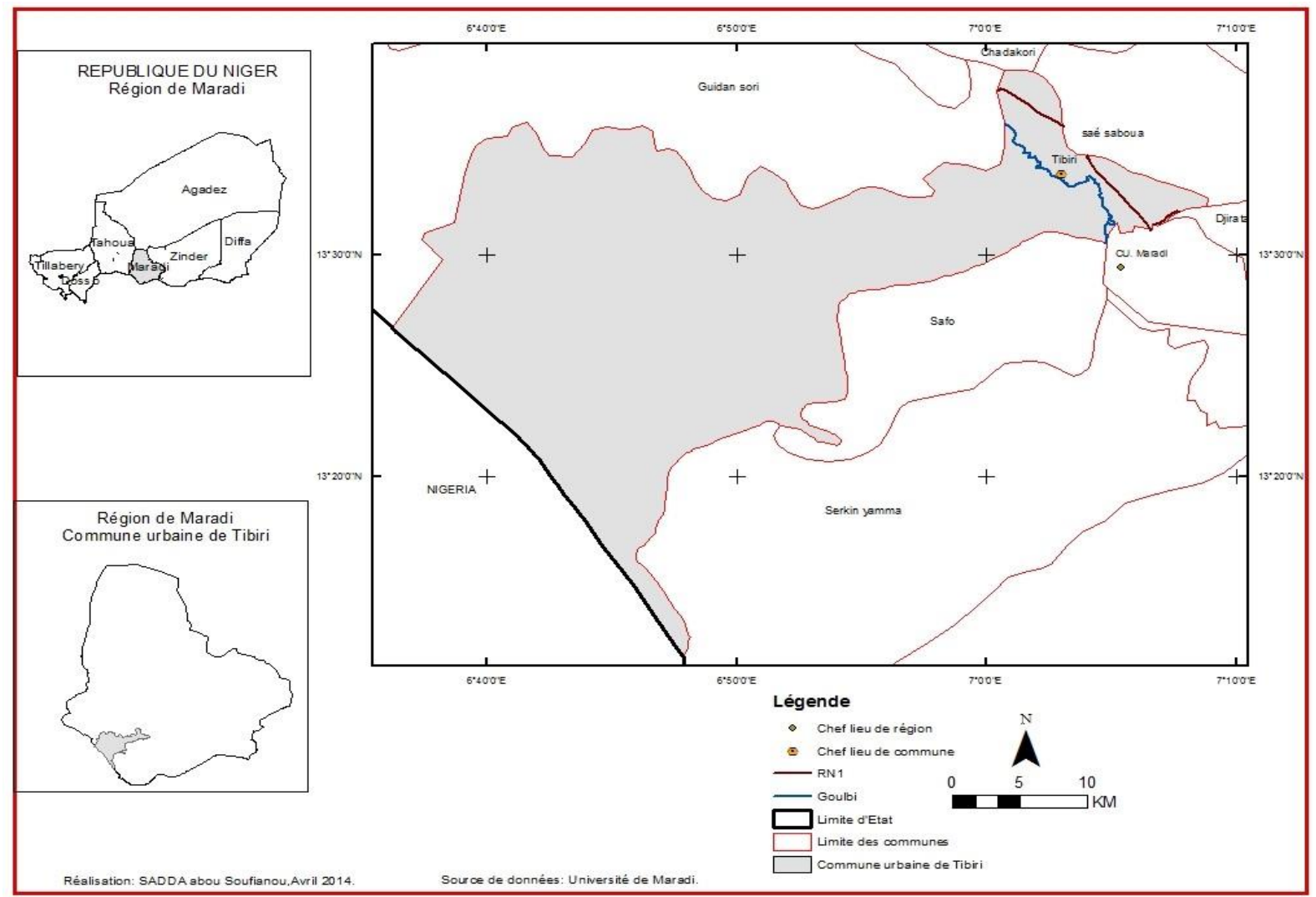

Figure 1: Map of the urban municipality of Tibiri 


\section{$>$ Sampling}

Sampling was carried out in the fields of the villages of Tibiri where assisted natural regeneration is the mode adapted by agriculture to maintain trees for various reasons. Thus, four transects were installed following a North-South and EastWest gradient. On each transect, plots of $2500 \mathrm{~m}^{2}(50 \mathrm{~m} \times 50 \mathrm{~m})$ as recommended by Thiobiano et al., (2016) equidistant from $300 \mathrm{~m}$ were prospected in the fields. A total of 20 readings were taken.

$>$ Data collection and analysis

\section{$\checkmark \quad$ Floristic surveys and dendrometric measurements}

The collection of floristic and dendrometric data was carried out in plots of $50 \mathrm{~m} \times 50 \mathrm{~m}$ during the rainy season. Thus twenty (20) plots were placed in the agrosystems according to homogeneity following an equidistance of $300 \mathrm{~m}$. The nomenclature of species adopted is that of Lebrun and Stork (1997). The dendrometric measurements concerned the total height, the diameter of the crown in the two perpendicular directions, the diameter of the trunk at $1.30 \mathrm{~m}$ from the ground for individuals at $\mathrm{dbh} \geq 5 \mathrm{~cm}$ and at $20 \mathrm{~m}$ from the ground for shrubs (Sambou, 2004; Ouédraogo, 2009). Individuals with a diameter of less than $5 \mathrm{~cm}$ are considered to be part of the regeneration (Mahamane and Saadou, 2008).

\section{$\checkmark$ Data analysis}

The data collected made it possible to establish the demographic structures of the ligneous plants through histograms of the distribution of relative frequencies calculated by class of diameter and height. To this end, amplitude classes of $5 \mathrm{~cm}$ and $4 \mathrm{~m}$ have been respectively defined for the diameters and heights. In addition, to better characterize the variability of the shapes of the observed structures and to make possible comparisons between structures, an adjustment to the theoretical Weibull distribution based on the maximum likelihood method was applied. This simple and flexible distribution fits perfectly both positive and negative skewed distributions, as well as normal ones (Lorimer and Krug, 1983; Baker et al., 2005). Its probability density function, $f$ is expressed by the formula:

$$
\mathbf{F}(\mathbf{x})=\frac{c}{b}\left(\frac{x-a}{b}\right)^{c-1} \exp \left[-\left(\frac{x-a}{b}\right)^{c}\right]
$$

With $\mathrm{c}$ the shape parameter (or Weibull slope) linked to the considered structure, and $\mathrm{b}$ the scale parameter linked to the central value of the probability distribution of the variable $\mathrm{x}=$ diameter. A value of $\mathrm{c}<1$, "inverted $\mathrm{J}$ " distribution is characteristic of multispecies or uneven-aged stands, while a value of $c>3.6$ is characteristic of stands predominantly of older individuals. In addition, if $1<\mathrm{c}<3.6$ this indicates stands with a predominance of young individuals or of small diameter.

In addition, the analysis of the species diversity was also made using Shannon-Weaver diversity and Pielou equitability indices and the species richness (number of species). These indices are expressed by:

$$
\text { Shannon index }\left(\mathrm{H}^{\prime}\right): \mathrm{H}=-\sum_{\mathrm{i}=1}^{\mathrm{s}} \mathrm{pi}\left(\log _{2} \mathrm{pi}\right)
$$

With pi $=\mathrm{ni} / \mathrm{N}$, relative abundance of species $\mathrm{i}$ in the total sample to which the species belongs, hence $\mathrm{N}=$ total number of individuals, $\mathrm{ni}=$ number of individuals of species $\mathrm{i}$. The $\mathrm{H}$ index is expressed in bits and is used to assess the heterogeneity and diversity of a biotope.

equitability of Pielou E = H / H_max, corresponds to the ratio between the observed diversity of Shannon $(\mathrm{H})$ and the maximum diversity (Hmax) possible given the number of species S. It is very useful for comparing the potential dominances between stations. where di: diameter (in meters) of tree i of the plot; s: surface area of the plot in $\mathrm{m}^{2}$ and $\pi=3.1416$.

The data collected also made possible to calculate the Importance Value Index (IVI) of Curtis and Macintosh (1951) cited by Traoré (1997) according to the formula IVI = Relative density + Relative dominance + Relative frequency (for the species). Where the relative dominance of a species is the quotient of its basal area with the total basal area of all species; the relative density of a species is the ratio of its absolute density to the total of the absolute densities of all species multiplied by one hundred and the relative frequency of a species is the ratio of its specific frequency to the total of the specific frequencies of all the species multiplied by one hundred.

\section{$>$ Data processing and analysis.}

The data collected was processed with Excel and Minitab18 softwares. 
Floristic composition and diversity of the woody stand

\section{RESULTS}

The floristic survey made it possible to identify 19 species divided into 18 genera and 9 families. The most represented families are the Fabaceae (72\%) and to a lesser extent the Anacardiaceae (7\%) (Figure 2). The other families represent $21 \%$ of the whole and some of which are represented by only one species, this is the case for example of Zygophyllaceae.

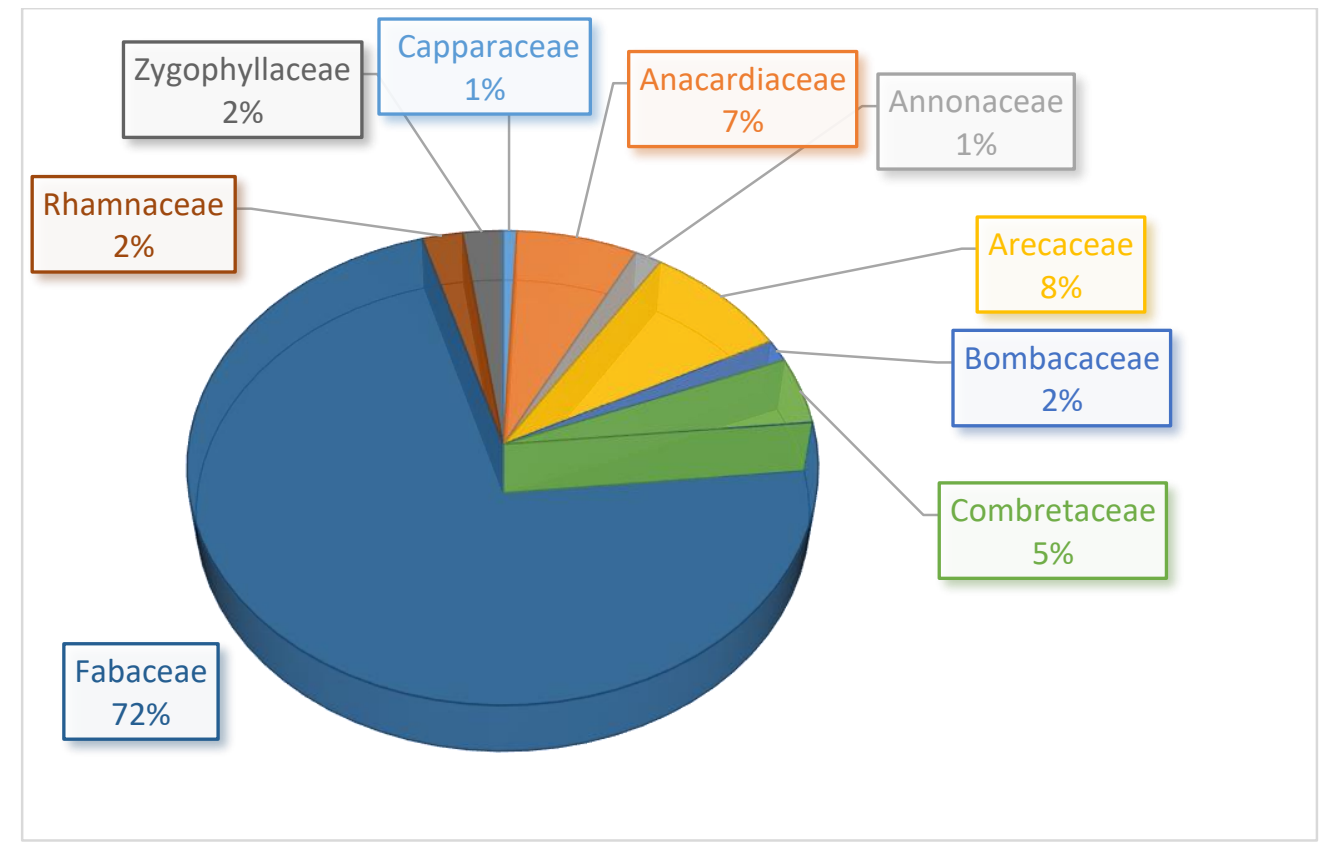

Figure 2: Representativeness of families

Figure 3 gives us the representativeness of the species inventoried on the site. The analysis of this figure shows that the most represented species are Piliostignma reticulatum (30\%), Faidherbia albida (17\%), Prosopis africana (14\%) and Hyphaene thebaica (8\%). On the other hand, Tamarindus indica, Ziziphus spina christi, Maerua crassifolia, Dichrostachys cinerea and Combretum glutinosum are the least represented with a representativeness of $1 \%$ each.

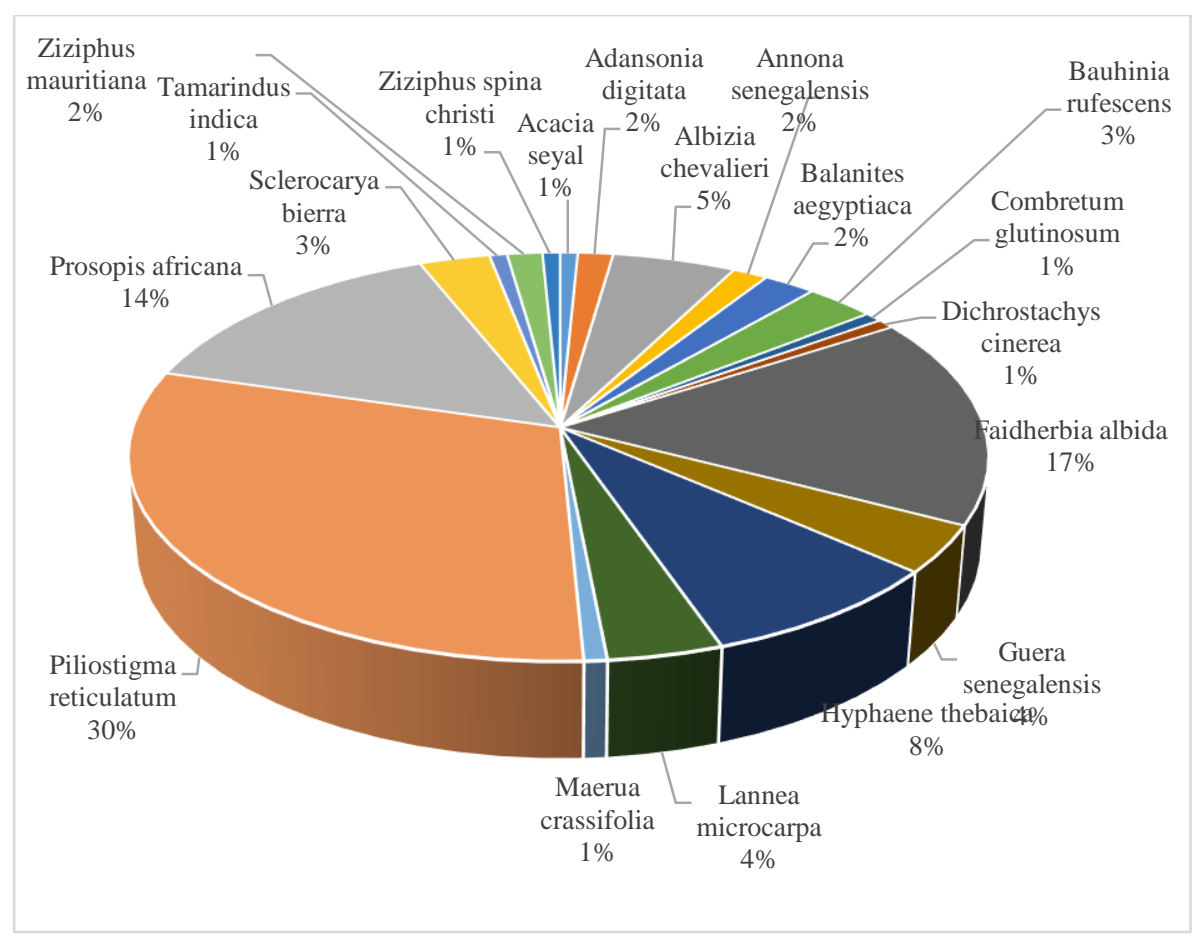

Figure 3: Representativeness of species 
The specific diversity of this agro-ecological zone is given by the Shannon $\mathrm{H}$ 'index and the equitability $\mathrm{E}$ of Pielou. The respective values of these indices are 3.26 bits and 0.767 bits.

In addition, the ecological importance of the species expressed by the Importance Value Index (IVI) is given in table 1. It emerges from the analysis of this table that the species which have the highest IVI values are Piliostigma reticulatum (77,0693), Faidherbia albida (55,7027), Prosopis africana $(43,7673)$ and Hyphaene thebaica $(23,4517)$ et. The cumulative number of their IVIs represents $66.66 \%$ of the total IVI. On the other hand, Acacia seyal, Maerua crassifolia, Dichrostachys cinerea and Tamarindus indica species have the lowest IVIs, thus accumulating less than $10 \%$ of the total IVI.

Table 1: Relative frequency, Relative dominance, Relative density and Importance Value Index of species listed on the site

\begin{tabular}{|l|l|l|l|l|l|}
\hline Especies & Effective & $\begin{array}{c}\text { Relative } \\
\text { frequency }(\%)\end{array}$ & $\begin{array}{c}\text { Relative } \\
\text { dominance }(\%)\end{array}$ & $\begin{array}{c}\text { Relative } \\
\text { density }(\%)\end{array}$ & IVI \\
\hline Piliostigma reticulatum & 40 & 22,2222 & 24,5441 & 30,3030 & 77,0693 \\
Faidherbia albida & 22 & 14,4444 & 24,5916 & 16,6667 & 55,7027 \\
Prosopis africana & 19 & 14,4444 & 14,9290 & 14,3939 & 43,7673 \\
Hyphaene thebaica & 11 & 7,7778 & 7,3406 & 8,3333 & 23,4517 \\
Albizzia chevalieri & 7 & 6,6667 & 4,2422 & 5,3030 & 16,2119 \\
Lannea microcarpa & 5 & 5,5556 & 5,2176 & 3,7879 & 14,5611 \\
Guiera senegalensis & 5 & 4,4444 & 1,0367 & 3,7879 & 9,2690 \\
Sclerocarya bierra & 4 & 4,4444 & 1,4929 & 3,0303 & 8,9676 \\
Bauhinia rufescens & 4 & 3,3333 & 2,2113 & 3,0303 & 8,5750 \\
Adansonia digitata & 2 & 2,2222 & 4,7825 & 1,5152 & 8,5198 \\
Balanites aegyptiaca & 3 & 3,3333 & 2,2265 & 2,2727 & 7,8325 \\
Ziziphus mauritiana & 2 & 2,2222 & 1,1664 & 1,5152 & 4,9037 \\
Ziziphus spina christi & 1 & 1,1111 & 2,5618 & 0,7576 & 4,4305 \\
Annona senegalensis & 2 & 2,2222 & 0,3749 & 1,5152 & 4,1123 \\
Combretum glutinosum & 1 & 1,1111 & 1,3777 & 0,7576 & 3,2464 \\
Acacia seyal & 1 & 1,1111 & 0,7106 & 0,7576 & 2,5793 \\
Maerua crassifolia & 1 & 1,1111 & 0,5740 & 0,7576 & 2,4426 \\
Dichrostachys cinerea & 1 & 1,1111 & 0,4377 & 0,7576 & 2,3064 \\
Tamarindus indica & 1 & 1,1111 & 0,1822 & 0,7576 & 2,0509 \\
\hline Total & 132 & 100 & 100 & 100 & 300 \\
\hline
\end{tabular}

\section{$>$ Woody stand structure}

The distribution of individuals by diameter class in the agro-ecological zone of Tibiri is given by Figure 4 . The diameter structure is dominated by individuals of small and medium diameter (from 25 to $65 \mathrm{~cm}$ ). These classes represent $87 \%$ of the total population. On the other hand, the individuals constituting the classes with a diameter greater than $90 \mathrm{~cm}$ only represent $1.51 \%$. In addition, the diameter structure of the ligneous trees has an "inverted J" shape and theoretically fits the theoretical Weibull distribution with the shape parameter $\mathrm{c}=1.959(1<\mathrm{C}<3.6)$, characteristic of stands with predominance of young individuals or of small diameter. 


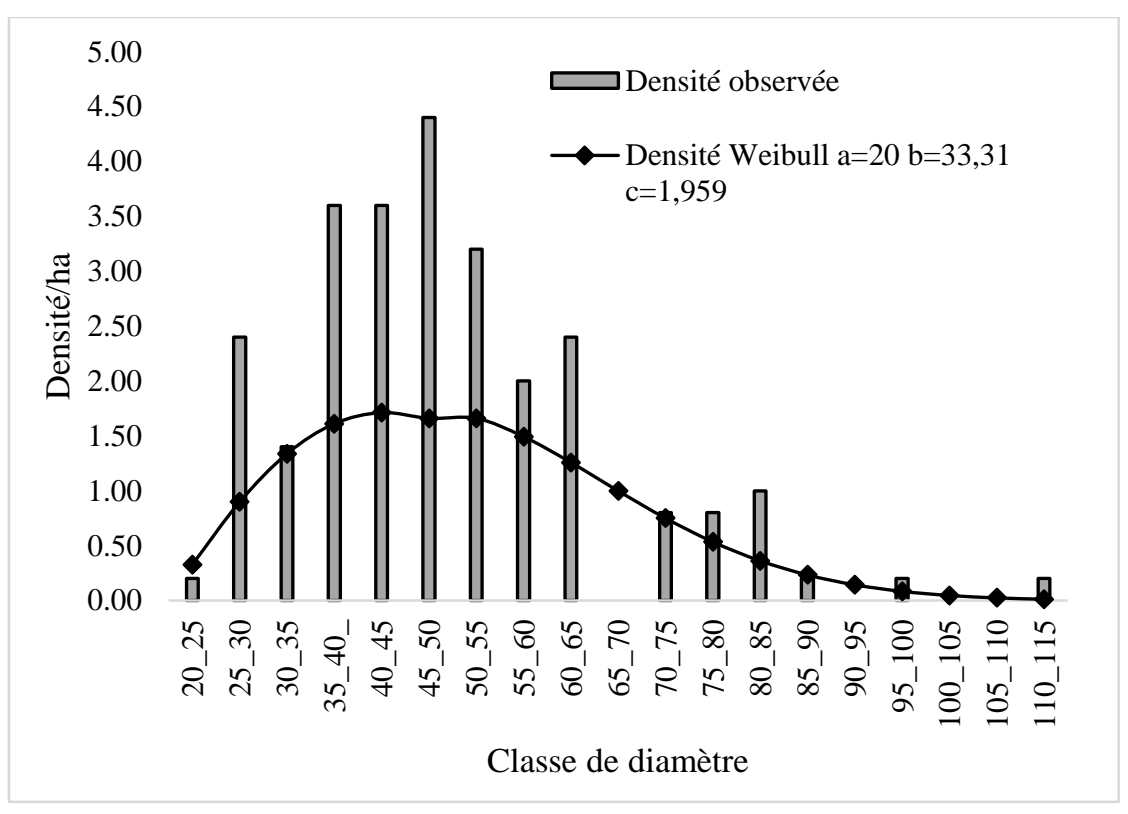

Figure 4: Diameter class structure of the stand woody resulting from the ANR

As for the vertical distribution (figure 5), the population is essentially grouped together in the height class of 4 to $8 \mathrm{~m}$ which includes $61.36 \%$ of the individuals surveyed followed by the height class of 8 to $12 \mathrm{~m}(27.27 \%)$. The height class greater than $12 \mathrm{~m}$ is the least represented $(5 \%)$.

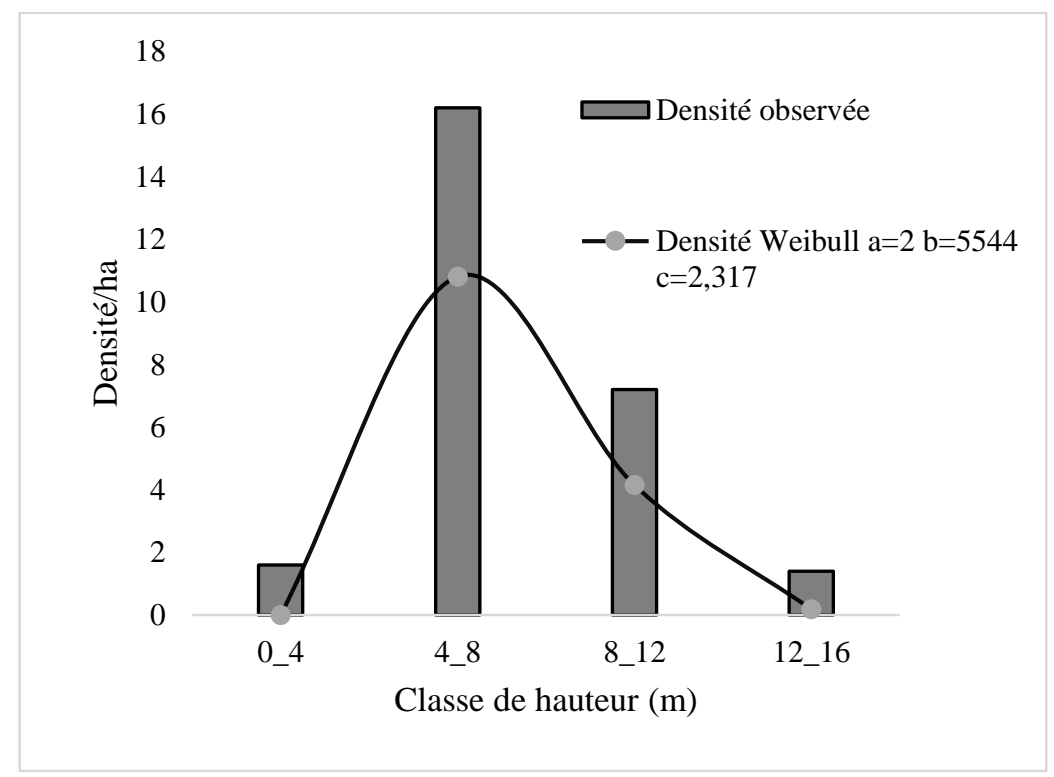

Figure 5: Height class structure of the stand resulting from the ANR

\section{$>$ Density of regenerating species}

The density of regenerating species is given in Table 2. The analysis of this table shows that the high density of regeneration (stem / ha) is observed in Guiera senegalensis representing $61.93 \%$ of the density of the inventoried species monitored of Piliostigma reticulatum (14.80\%). On the other hand, species such as: Sclerocarya birrea and Ziziphus mauritiana have the low density, each representing $0.60 \%$ of the total density. The total regeneration density in this area is 2648 stems / ha, grouped together in eleven (11) species testifying to good regeneration as it ranges between 1000 and 10,000 stems / ha. 
Table 2: Density of regenerating species

\begin{tabular}{|l|c|c|}
\hline Espèces & $\begin{array}{l}\text { Densité } \\
\text { (tige/ha) }\end{array}$ & $\begin{array}{l}\text { Fréquence } \\
\text { relative (\%) }\end{array}$ \\
\hline Albizzia chevalieri & 96 & 3,63 \\
\hline Annona senegalensis & 108 & 4,08 \\
\hline Calotropis procera & 24 & 0,91 \\
\hline Combretum glutinosum & 48 & 1,81 \\
\hline Faidherbia albida & 28 & 1,06 \\
\hline Guiera senegalensis & 1640 & 61,93 \\
\hline Hypaene thebaica & 140 & 5,29 \\
\hline Piliostigma reticulatum & 392 & 14,80 \\
\hline Prosopis africana & 140 & 5,29 \\
\hline Sclerocarya birrea & 16 & 0,60 \\
\hline Ziziphus mauritiana & 16 & 0,60 \\
\hline Total & 2648 & 100,00 \\
\hline
\end{tabular}

\section{$>$ Height structure of the regeneration}

The height distribution of regeneration is given by figure 6. It emerges from the analysis of this figure that the most represented individuals are grouped together in the height class greater than or equal to $2 \mathrm{~m}$ and represent $34.21 \%$ of the individuals listed, followed by the 1 to 1.5 meter height class (27.63\%). The $0.5-1 \mathrm{~m}$ height class is not shown.

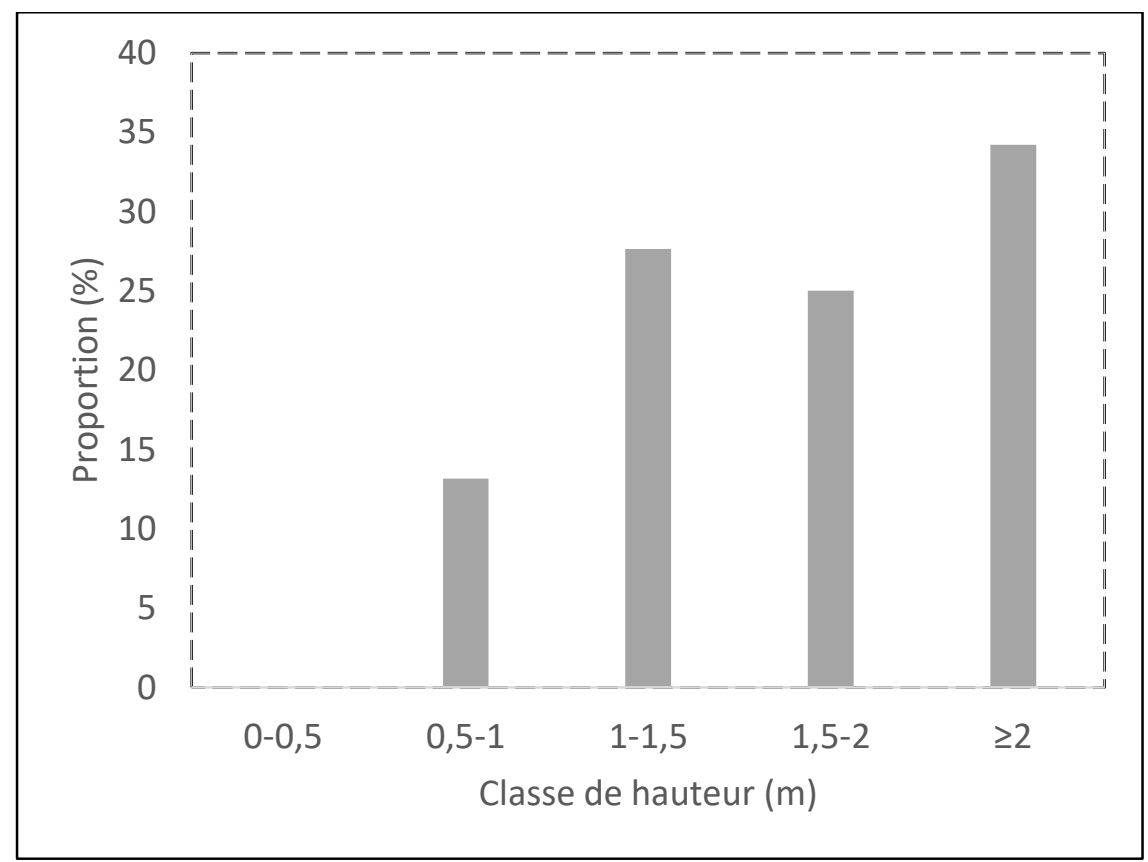

Figure 6: Height class structure of the regeneration

\section{$>$ Floristic composition and diversity of the woody stand \\ 4. DISCUSSION}

The floristic inventory of the agecozone of Tibiri made it possible to identify 19 species distributed in 9 families largely dominated by Fabaceae, which represent more than $72 \%$ of the families present on the land. This domination of the Fabaceae would be related to the fact that this family includes the species most represented in the fields. These are Piliostignma reticulatum (30\%), Faidherbia albida (17\%), Prosopis africana (14\%). The choice to conserve these species is that they would improve crop yields. Indeed, Producers recognize that the level of soil fertility is higher under the canopy of certain tree species than on bare soil. Borassus aethiopum and Faidherbia albida rank first among the species guaranteeing soil fertility, respectively in the sites with Vitellaria paradoxa and Neocarya macrophylla. According to farmers, the fields with these species never lose their fertility level and produce 2-3 times more than a bare field (Iro, 2011). According to the same author, Piliostigma reticulatum, Hyphaene thebaica and Guiera senegalensis are also appreciated by producers for their fertilizing role..They really coop with cereals which develop best around their clumps. The findings 
of this study are in line with with those of Abdourhamane et al., (2013) who report that the formations of agrosystems made up of fallows, $S$. birrea agroforestry parks and fields are relatively richer (20 species).

The value of 3.26-bit of Shannon's index H' is greater than 2.5bits. This means that the woody biodiversity is high. These results are consistent with those reported by Iro et al., (2011) in the parks with Vitellaria paradoxa (3.05 bits) and in the fields ( 2.25 bits). This shows that fields with assisted natural regeneration have more woody biodiversity than other types of fields. Likewise, the Pielou equitability value of 0.767 bits obtained within the framework of this study is greater than that reported by these authors 0.59 and is closer to 1 . Which suggests that this agroecological zone is more stable than the parks with Vitellaria paradoxa and even with Neocarya macrophylla. This value of the Shannon index is higher than those reported by Abdourhamane et al. (2013) for the Sclerocarya birrea Park and the fields which are respectively 2.30 and 2.38 bits. This further corroborates the idea that ANR fields are much more diverse than other types of fields, namely Agroforestry Parks and better, even conventional fields. Moussa et al., (2015) reported 9 families in the $F$. albida parks of Dan Mairo and 17 families in the P. africana park of Sarkin Yamma and that these parks are dominated by Mimosaceae and Caesalpiniaceae. Shannon-Weaver diversity indices are equal to 2.27bits and 2.42bits respectively for the $F$. albida and $P$. africana parks. The Piélou equitabiliy index is 0.57 and 0.56 respectively for the $F$. albida and $P$. africana parks. By comparing the results of this study with those of this author, one can assert that fields contribute to the diversification of woody biodiversity.

\section{$>$ Stand woody structure}

The analysis of the structure of the woody stand is carried out from the distribution by diameter classes. The diameter class structure is characterized by the predominance of individuals of small and medium diameters. Such a structure, qualified as classic, is often observed for undisturbed forest ecosystems (Adjonou et al., 2009). This justifies that stands resulting from assisted natural regeneration compare favorably with natural stands. Large diameter individuals are rare in most of the population, this rarity of large diameter individuals results in the inability of individuals to grow normally due to cumulative water deficits (Osseina et al., 2015). One can also assert that this scarcity of large-diameter individuals is linked to the abundance of microphanerophytes and nanophanerophytes in the study area. This observed structure fits a theoretical Weibull distribution with a shape parameter $c=1.959$ characteristic of stands predominantly of young individuals or of small diameter. Values of the form c between 1 and 3.6, characteristic of populations predominantly of young or small-diameter individuals, have been obtained by several authors (Karim, 2013; Abdourhamane et al., 2013; Rabiou et al. , 2015).

\section{$>$ Regeneration}

The species most represented in regeneration are Guiera senegalensis and Piliostigma reticulatum. On the other hand, Sclerocarya birrea and Ziziphus mauritiana are the least represented. The weak regeneration of species in particular $L$. microcapa, A. chevalieri, A. senegalensis, and S. birrea, would be related to the insufficiency or absence of seeds of these species due to the fact that they are rarely represented by adults or that they are consumed by the populations. These observations are in agreement with the results of Niang et al., (2014) and Dan Guimbo et al., (2011). The strong regeneration of other species such as $P$. reticulatum, $G$. senegalensis, $C$. glutinosum, Hyphaene thebaica, A. senegalensis and Z. mauritiana is explained by their capacity to emit suckers following clearing during the installation of cultures (Moussa et al., 2015). The same observations are made by Larwanou and Sâadou (2012) on the regeneration of restored sites in Niger. As for $F$. albida, $P$. africana and A. chevalieri, their regeneration seems to be mixed because very few rejections of strains relating to these species have been observed. For these species, pods and seeds are highly valued by populations, thus reducing the regeneration capacity of these species (Moussa et al., 2015). In the Neocarya macrophylla park, regeneration consists of 16 and 5 species respectively in fields and grazing areas. The overall density is 2853 and 6984 juvenile individuals / ha respectively in fields and grazing areas. The distribution of species by regeneration mode, as in the Vitellaria paradoxa park, shows that the species regenerate mainly by rejecting stumps and weakly by sowing (Iro, 2011). These results corroborate those of this study in that they allow us to assert that regeneration is as good in ANR fields as in agroforestry parks and grazing areas; the density reported by this study being 2648 stems /ha testifying a good regeneration because it is between 1000 and 10,000 stems/ha.

\section{CONCLUSION}

This study carried out in the territory of the Municipality of Tibiri made it possible to assess the contribution of assisted natural regeneration (ANR) to woody biodiversity. In fact, 19 species have been inventoried, divided into 18 genera and 9 families. The most represented families are the Fabaceae and to a lesser extent the Anacardiaceae. As for the species listed, the most represented are Piliostignma reticulatum, Faidherbia albida, Prosopis africana and Hyphaene thebaica. The regeneration is made up of eleven (11) species, the most represented of which are Guiera senegalensis and Piliostigma reticulatum, the total density of the stems is 2648 stems/ha testifying good regeneration. The diversity of the ligneous plants to which this study is referring to is not only greater than that of certain agroforestry parks but also stable, taking into account the values of the Shannon and Piélou indices. 


\section{REFERENCES}

Adjonou K., Ali N., Kokutse A. D. Segla K. N., Kokou K., 2010. Étude de la dynamique des peuplements naturels de $P$. erinaceus Poir. (Fabaceae) surexploités au Togo. Bois et Forêts des Tropiques, 306 (1) : 33-43.

Baggnian I., Adamou M. M. Adam T. et Mahamane A., 2013. Impact des modes de gestion de la Régénération Naturelle Assistée des ligneux (RNA) sur la résilience des écosystèmes dans le Centre-Sud du Niger. J. Appl. Biosci. 71 : $5742-5752$.

Baker P.J., Bunyavejchewin S., Oliver C.D., Ashton P.S., 2005. Disturbance history and historical stand dynamics of a seasonal tropical forest in western Thailand. Ecology Monographs, 75: 317-343.

Dan Guimbo I., Mahamane A., Ambouta K. J-M., 2010 : Peuplement des parcs à Neocarya macrophylla (Sabine) Pranceet à Vitellaria paradoxa (Gaertn. C.F.) dans le sud-ouest nigérien : Diversité, structure et régénération. Int. J. Biol. Chem. Sci. 4 (5) : 1706-1720.

Dan Guimbo I., Mahamane A., Ambouta K. J-M., 2010 : Peuplement des parcs à Neocarya macrophylla (Sabine) Pranceet à Vitellaria paradoxa (Gaertn. C.F.) dans le sud-ouest nigérien : Diversité, structure et régénération. Int. J. Biol. Chem. Sci. 4 (5) : 1706-1720.

Dan. Guimbo I., 2011. Fonction, dynamique et productivité des parcs à Vitellaria paradoxa C.F. Gaertn. et à Neocarya macrophylla (Sabine) Prance dans le sud-ouest du Niger. Thèse de doctorat en Sciences de l'Environnement. 158p

Karim S., 2013. Dynamique de la biodiversité végétale suivant un gradient pluviométrique et un gradient d'utilisation des terres dans les observatoires de Falmey-Gaya et Tahoua- Tillabéry Nord (Niger). Thèse de doctorat en Botanique et Ecologie Végétales. Université Abdou oumouni de Niamey. Option : Biologie et Ecologie appliquées $136 \mathrm{p}$

Larwanou M., Saâdou M., Hamadou S., 2006. Les arbres dans les systèmes agraires en zone sahélienne du Niger : mode de gestion, atouts et contraintes. Tropicultura, 24(1): 14-18.

Larwanou, M., M. Abdoulaye et C. Reij (2006) - Etude de la Régénération Naturelle Assistée dans la Région de Zinder (Niger). USAID/IRG-FRAME. 2 P,

Lebrun J. P., Stork A. L., 1997. Enumération des Plantes à Fleurs d'Afrique Tropicale (Vol. IV). Conservatoire et Jardin botanique de Genève.

Lorimer C.G., KRUG A.G., 1983. Diameter distribution in even-aged stands of shade-tolerant and midtolerant tree species. Amrican Midland Naturalist, 109: 331-345.

Mahamane A, Saadou M., 2008. Méthode d'étude de la flore et de la végétation tropicale. Project SUN-EU. Actes de l'atelier sur l'harmonisation des méthodes, $83 \mathrm{p}$.

Moussa M., Larwanou M., Saadou M., 2015. Caractérisation des peuplements ligneux des parcs à Faidherbia albida (Del) A. Chev. et à Prosopis africana (Guill., Perrot et Rich.) Taub. du Centre-Sud Nigérien. J. Appl. Biosci. 94:8890 8906

Rabiou H., Abdoulaye D.F, 2015 : Structure des peuplements naturels de Pterocarpus erinaceus Poir. dans le domaine soudanien, au Niger et au Burkina Faso Bois et forêts destropiques, 2015, n 325 (3).

Sambou B. 2004. Evaluation de l'état, de la dynamique et des tendances évolutives de la flore et de la végétation ligneuses dans les domaines soudanien et subguinéen au Sénégal. Thèse de doctorat, Université Cheikh Anta Diop, 248p.

Ouédraogo O. 2009. Phytosociologie, dynamique et productivité de la végétation du parc national d'Arly (Sud-Est du Burkina Faso). Thèse de doctorat de l'Université de Ouagadougou, 188p.

Traoré SA. 1997. Analyse de la flore ligneuse et de la végétation de la zone de Simenti (parc National du Niokolo Koba), Sénégal Oriental. Thèse de Doctorat de 3ème cycle en biologie végétale, Université Cheikh Anta Diop de Dakar, $147 \mathrm{p}$. 